\title{
PENGARUH PENGGUNAAN TANAMAN AZOLLA YANG DIFERMENTASI TERHADAP PERTUMBUHAN IKAN NILA (Oreochromis niloticus) DI DESA RIKIT BUR, KECAMATAN BUKIT TUSAM
}

\section{THE EFFECT OF THE USE OF FERMENTED AZOLLA PLANT ON THE GROWTH OF Tilapia (Oreochromis niloticus) IN RIKIT BUR VILLAGE, BUKIT TUSAM DISTRICT}

\author{
Ilhamdi ${ }^{*}$, Kurnia Sada Harahap ${ }^{2}$ \\ ${ }_{1}^{1}$ Politeknik Kelautan dan Perikanan Pariaman, Pariaman, Provinsi Sumatera Barat, Indonesia \\ 2Politeknik Kelautan dan Perikanan Dumai, Jl. Wan Amir, No.1, Kelurahan Pangkalan Sesai, \\ Kecamatan Dumai Barat, Kota Dumai, Provinsi Riau, Indonesia \\ *Korespondensi: ilhamdicaneago@gmail.com (Ilhamdi) \\ Diterima 26 Agustus 2020 - Disetujui 30 September 2020
}

\begin{abstract}
ABSTRAK. Penelitian ini bertujuan untuk menerangkan tentang pengertian dan keunggulan tanaman azolla pada masyarakat dan mengetahui penggunaan tanaman azolla yang difermentasi terhadap pertumbuhan ikan nila. Penelitian dilakukan menggunakan metode eksperimen dengan menggunakan Rancangan Acak Lengkap (RAL) dengan 4 perlakuan yaitu tanaman azolla yang difermentasi (P1) $0 \%$ tanpa campuran bahan lain (kontrol), (P2) tanaman azolla yang difermentasi $45 \%$, (P2) tanaman azolla yang difermentasi $35 \%$, dan (P3) tanaman azolla yang difermentasi $20 \%$. Paramater yang diamati adalah pertumbuhan mutlak benih ikan nila. Hasil penelitian menunjukkan bahwa antar perlakuan diperoleh rata-rata pertumbuhan mutlak ikan nila dengan signifikasi $(P<0,05)$. Media fermentasi P0 meningkatkan pertumbuhan mutlak ikan nila 32,598 gram, P1 meningkatkan pertumbuhan mutlak ikan nila 32,386 gram, P2 meningkatkan pertumbuhan mutlak ikan nila 33,880 , dan P3 pertumbuhan mutlak ikan nila 32,650 gram. Kemudian dengan Uji Analisis Variansi (ANOVA) menghasilkan Fhitung 1,00 lebih kecil dari Ftabel 4,07 pada taraf $5 \%$, maka $\mathrm{H} 1$ di tolak. Jadi penggunaan tanaman azolla yang difermentasi tidak berpengaruh nyata terhadap pertumbuhan ikan nila di Desa Rikit Bur Kecamatan Bukit Tusam. Artinya bahwa penggunaan tanaman azolla yang difermentasi belum dapat memenuhi kebutuhan harian ikan nila dalam jangka waktu 56 hari.
\end{abstract}

KATA KUNCl: Tanaman azolla, fermentasi, pertumbuhan ikan nila

ABSTRACT. This study aims to explain the understanding and advantages of azolla plants in the community and to determine the use of fermented azolla plants for the growth of tilapia. The research was conducted using an experimental method using a completely randomized design (CRD) with 4 treatments, namely azolla plants fermented (P1) $0 \%$ without a mixture of other ingredients (control), (P2) azolla plants fermented $45 \%$, (P2) azolla plants which $35 \%$ fermented, and (P3) azolla plants 20\%. The parameters observed were the absolute growth of tilapia seeds. The results showed that between treatments the absolute growth rate of tilapia was obtained with significance $(P<0.05)$. The fermentation medium $P 0$ increased the absolute growth of tilapia 32.598 grams, $P 1$ increased the absolute growth of tilapia 32.386 grams, $P 2$ increased the absolute growth of tilapia 33.880, and P3 increased absolute growth of tilapia 32.650 grams. Then with the Analysis of Variance Test (ANOVA) produces Fcount 1.00 smaller than Ftable 4.07 at the 5\% level, then $\mathrm{H} 1$ is rejected. So the use of fermented azolla plants has no significant effect on the growth of tilapia in Rikit Bur Village, Bukit Tusam District. This means that the use of fermented azolla plants has not been able to meet the daily needs of tilapia within 56 days.

KEYWORDS: Azolla plant, fermentation, growth of tilapia 


\section{Pendahuluan}

Usaha budidaya ikan sangat dipengaruhi oleh ketersediaan pakan yang cukup dalam jumlah dan kualitasnya untuk mendukung kualitas yang maksimal. Faktor pakan menentukan biaya produksi mencapai $60-70 \%$ dalam usaha budidaya ikan sehingga perlu pengelolaan yang efektif dan efisien. Beberapa syarat bahan pakan yang baik untuk diberikan adalah memenuhi kandungan gizi (protein, lemak, karbohidrat, vitamin dan mineral) yang tinggi, tidak beracun, mudah diperoleh, mudah diolah dan bukan sebagai makanan pokok manusia.

Pakan buatan adalah salah satu faktor penting dalam usaha budidaya ikan intensif karena merupakan biaya variabel terbesar dalam proses produksi yakni $40 \%-60 \%$ (Webster \& Liem, 2002). Salah satu kendala yang dihadapi dalam pembuatan pakan adalah ketersediaan bahan baku. Data Direktorat Produksi, Dirjen Perikanan Budidaya, Kementerian Kelautan dan Perikanan (2009) menyatakan bahwa bahan baku pakan ikan yang diimpor tersebut antara lain adalah tepung ikan, tepung cumi-cumi, tepung krustasea, Meat Bone Meal (MBM), Poultry Meat Meal (PMM), tepung kedelai, terigu, serta berbagai jenis vitamin dan mineral dengan total nilai impor pada tahun 2008 mencapai US\$ 132.367.966,81. Oleh karena itu, perlu dicari bahan baku pakan alternatif yang murah, berkualitas, dan dapat tersedia sepanjang waktu.

Ada beberapa alternatif bahan pakan yang dapat dimanfaatkan dalam penyusunan pakan salah satunya adalah tanaman Azolla. Tanaman Azolla merupakan gulma air yang tidak termanfaatkan, tetapi memiliki kandungan protein yang cukup tinggi, yaitu 28,12\% berat kering (Handajani, 2000), sedangkan Lumpkin dan Plucknet (1982) menyatakan kandungan protein pada Azolla sp. sebesar $23,42 \%$ berat kering dengan komposisi asam amino esensial yang lengkap.

Pelet herbal merupakan pakan ikan buatan dengan bahan baku utama berbasis tumbuhan. Daun mata lele atau Azolla sp. berpotensi untuk digunakan sebagai bahan baku pelet herbal dan mempunyai kandungan nutrien yang baik meliputi (dalam berat kering) 10-25\% protein, 10-15\% mineral, dan 7-10\% asam amino (Marhadi, 2009). Kendala utama dalam pemanfaatan bahan nabati termasuk tanaman azolla sebagai bahan baku pakan ikan adalah tingginya kandungan serat kasar dan adanya kandungan zat anti-nutrisi serta komposisi asam amino yang berbeda dengan bahan baku protein hewani. Kandungan serat kasar yang terdapat dalam tanaman azolla atau daun mata lele adalah sebesar 23,06 \% (Handajani, 2007). Salah satu upaya yang dapat dilakukan untuk mengatasi kendala tersebut adalah dengan teknologi fermentasi. Oleh sebab itu penulis ingin melakukan penelitian yang lebih mendalam tentang penggunaan tanaman azolla yang difermentasikan terhadap pertumbuhan ikan nila.

\section{Bahan dan Metode}

\subsection{Waktu dan Lokasi Penelitian}

Penelitian dilaksanakan dari bulan April sampai dengan Juni 2019 yang dilakukan di Desa Rikit Bur Kecamatan Bukit Tusam.

\subsection{Alat dan Bahan Penelitian}

Alat yang digunakan pada penelitian ini yaitu drum, timbangan, baskom, tangguk, karung dan cangkul atau sekop. Bahan yang digunakan dalam penelitian ini adalah benih ikan nila sebanyak 200 ekor dengan ukuran besar antara 5-8 cm/ekor dan tanaman azolla. Bahan pembuat pakan yaitu ikan nila, tanaman azolla, pupuk organik (pupuk kandang), jerami padi, karung, dedak/bekatul, dan EM4.

\subsection{Metode Penelitian}

Penelitian ini menggunakan metode eksperimen dengan Rancangan Acak Lengkap. Untuk menguji pertumbuhan ikan nila dilakukan 4 perlakuan dan 3 kali ulangan, yaitu : berbagai tingkat penggunaan tepung kedelai dan tepung azolla dalam pakan buatan $\mathrm{PO}=$ tanaman azolla yang 
difermentasi $0 \%$ tanpa campuran lain (kontrol), P1 = tanaman azolla yang difermentasi $45 \%+$ pupuk organik $15 \%$, jerami padi $10 \%$ + dedak $10 \%+$ EM4 $10 \%$, P2 = tanaman azolla yang difermentasi 35 $\%$, pupuk organik $10 \%$, jerami padi $5 \%+$ dedak $10 \%$, EM4 $5 \%$, dan P3 = tanaman azolla yang difermentasi $20 \%$, + pupuk organik $5 \%$ + jerami padi $5 \%$, dedak $5 \%+$ dan EM4 $5 \%$.

Wadah penelitian berupa keramba jaring kassa dengan ukuran $1 \times 1 \times 1 \mathrm{~cm}$ berjumlah 12 buah dengan kepadatan 10 ekor per keramba jaring kassa. Ikan uji berukuran $5-8 \mathrm{~cm}$ dengan berat 3,00 gram perekornya.

\subsection{Parameter Pengamatan}

Data-data yang telah didapatkan pada saat pengamatan dianalisis dari beberapa parameter yaitu laju pertumbuhan mutlak ikan nila.

\section{Hasil dan Pembahasan}

\subsection{Laju Pertumbuhan}

Mudjiman (2004) menyatakan bahwa laju pertumbuhan adalah perbedaan pertumbuhan mutlak yang terukur berdasarkan urutan waktu. Pertumbuhan dapat dibagi dua, yaitu pertumbuhan mutlak dan pertumbuhan relatif. Pertumbuhan mutlak adalah rata-rata ukuran total tiap umur. Sedangkan pertumbuhan harian adalah persentase pertambahan pertumbuhan tiap selang waktu.

Hasil pengamatan laju pertumbuhan mutlak terhadap benih ikan nila memberikan hasil yang berbeda dari masing-masing perlakuan selama 56 hari pemeliharaan. Berat rata-rata benih ikan nila dapat dilihat dibawah ini:

Tabel 1. Berat Rata-Rata Benih Ikan Nila di Lokasi Penelitian

\begin{tabular}{|c|c|c|c|c|c|c|}
\hline \multirow{2}{*}{ Perlakuan } & \multicolumn{5}{|c|}{ Pengamatan Hari Ke- } & \multirow{2}{*}{$\begin{array}{l}\text { Pertumbuhan } \\
\text { (gram) }\end{array}$} \\
\hline & 0 & 14 & 28 & 42 & 65 & \\
\hline P0 & 3.20 & 4.41 & 5.80 & 15.54 & 18.24 & 32.598 \\
\hline P1 & 3.17 & 4.43 & 5.57 & 15.49 & 18.63 & 32.386 \\
\hline P2 & 3.21 & 4.52 & 5.69 & 16.62 & 19.20 & 33.880 \\
\hline P3 & 3.18 & 4.48 & 5.90 & 15.35 & 18.70 & 32.650 \\
\hline
\end{tabular}

Sumber: Data Primer, 2019.

Berdasarkan grafik pertumbuhan perbedaan pertumbuhan mutlak antar perlakuan mulai terlihat pada hari ke 14. Kecenderungan itu semakin tajam sampai hari ke-65. Grafik pertumbuhan ikan nila selama pengamatan dapat dilihat pada Gambar 1.

Dari data di atas diketahui bahwa perlakuan yang memberikan laju pertumbuhan mutlak tertinggi dicapai pada perlakuan P2 dengan tingkat substitusi $35 \%$ tanaman yang difermentasi, pupuk organik $10 \%$, jerami padi $5 \%$, dedak $10 \%$ dan EM4 $5 \%$ sebesar 33,880 gram. Dari hasil perhitungan statistik diperoleh sidik ragam seperti tertera pada tabel berikut:

Tebel 2. Daftar Sidik Ragam Pertumbuhan Mutlak Ikan Nila

\begin{tabular}{lccccc}
\hline \multicolumn{1}{c}{ Sumber Keragaman } & db & JK & KT & Fhitung & Ftabel \\
\hline Perlakuan & 3 & 66.17 & 22.05 & 1.00 & 4.07 \\
Galat & 8 & 176.26 & 22.03 & & \\
Total & 11 & 242.43 & & & \\
\hline
\end{tabular}

Sumber: Data Primer, 2019. 
Dari hasil perhitungan sidik ragam pada tabel di atas, tersebut menunjukkan hasil bahwa, perlakuan penggunaan tanaman azolla yang difermentasi terhadap pertumbuhan ikan nila tidak memberikan pengaruh yang nyata terhadap pertumbuhan harian pada ikan nila.

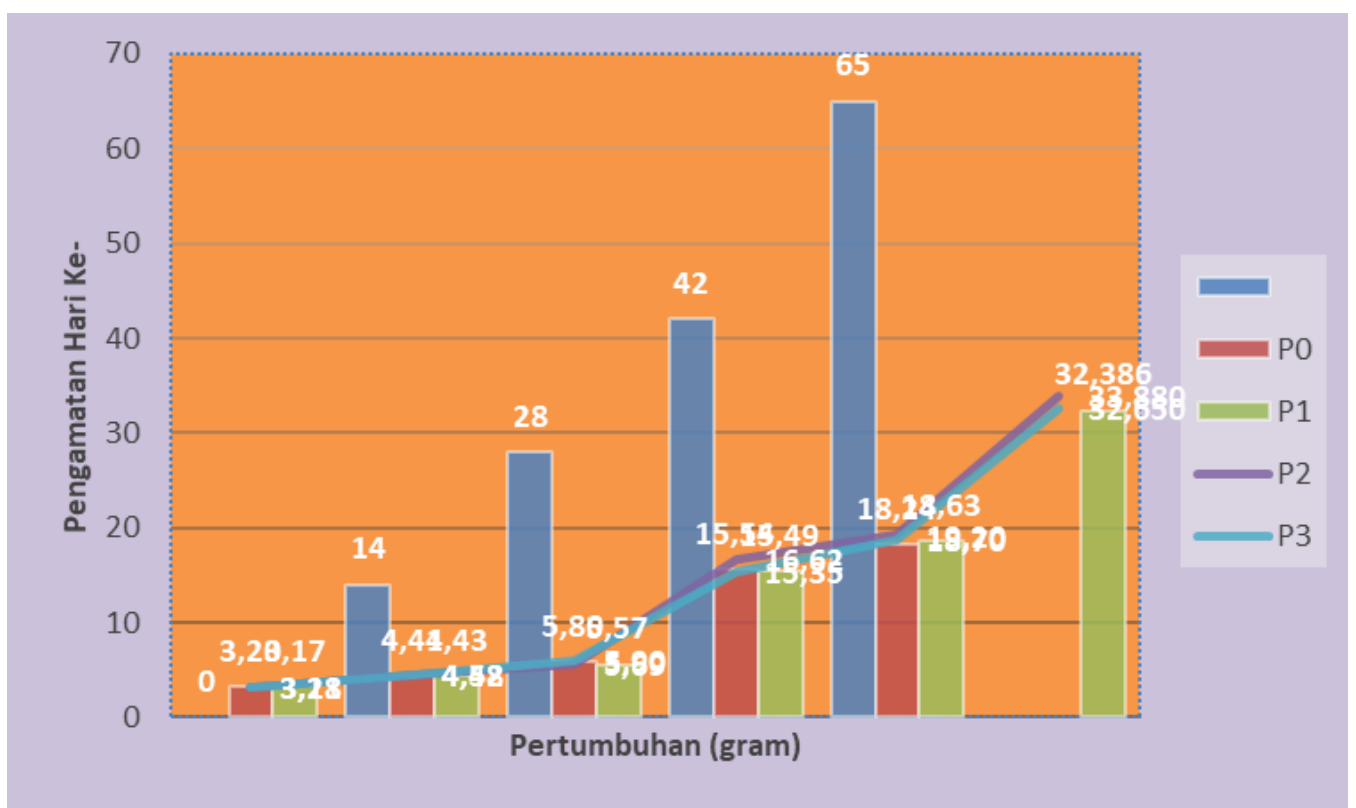

Keterangan: $\mathrm{P} 0=$ tanaman azolla yang difermentasi $0 \%$ tanpa diberi campuran lain (kontrol); $\mathrm{P} 1=$ tanaman azolla yang difermentasi $45 \%$ + pupuk organik $15 \%$ + jerami padi $10 \%$ + dedak $10 \%+$ EM4 $10 \% ;$ P2 = tanaman azolla yang difermentasi $35 \%+$ pupuk organik $10 \%+$ jerami padi $5 \%$ + dedak $10 \%+$ EM4 $5 \%$; P3 = tanaman azolla yang difermentasi $20 \%+$ pupuk organik $5 \%+$ jerami padi $5 \%+$ dedak $5 \%+$ dan EM $45 \%$.

\section{Gambar 1. Grafik Hubungan Perlakuan dan Pertumbuhan Mutlak Ikan Nila selama Penelitian}

\subsection{Pembahasan}

Penelitian ini melakukan rekayasa bahan baku dengan teknologi sederhana berupa tanaman azolla yang difermentasi dengan campuran bahan baku lain seperti pupuk organik, jerami padi, dedak dan EM4. Hasil fermentasi tanaman azolla menunjukkan pertumbuhan mutlak antar perlakuan mulai terlihat pada hari ke 14. Kecenderungan itu semakin tajam sampai hari ke-65.

Peningkatan pertumbuhan mutlak ikan nila ini disebabkan tumbuhnya pakan alami di kolam seperti moina sp dan dapnia sp. Karena waktu 1 minggu sebelum ikan dimasukkan ke kolam dengan media jaring kassa beserta tanaman azolla yang difermentasi, maka pada saat itu berkembanglah pakan alami tersebut. Dan pakan alami tersebut sangat baik bagi pertumbuhan ikan nila.

Penggunaan tanaman azolla yang difermentasi berpengaruh terhadap pertumbuhan ikan nila yaitu dengan berat 33,880 gram (P2). Karena adanya campuran bahan lain seperti pupuk organik, jerami padi, dedak dan probiotik EM4 dengan perlakukan masing-masing.

\section{Kesimpulan}

Kesimpulan yang dapat ditarik dari hasil penelitian ini adalah penggunaan tanaman azolla baik digunakan sebagai pakan alternatif (tambahan) untuk memacu pertumbuhan ikan nila. Pemberian pupuk organik dan probiotik mampu meningkatjan kandungan nitrogen didalam kolam. Semakin lama proses fermentasi dan pupuk organik dan probiotik juga ditambah maka pakan alami dan kandungan nitrogen akan semakin banyak dan ini dapat memacu pertumbuhan ikan nila. 


\section{DAFTAR PUSTAKA}

Badan Pusat Statistik (BPS). 2013. Kabupaten Aceh Tenggara Dalam Angka. Provinsi Aceh.

Dinas Perikanan Kabupaten Aceh Tenggara. (2012). Luas Lahan, Produksi Budidaya Air Tawar. Tahun 2012.

Effendie, M.I. (2002). Biologi Perikanan. Yayasan Pustaka Nusantara, Yogyakarta. Hal 96-106.

Handajani. (2000a). Peningkatan kadar protein tanaman Azolla microphylla dengan mikrosimbion Anabaena azollae dalam berbagai konsentrasi $\mathrm{N}$ dan $\mathrm{P}$ yang berbeda pada media tumbuh.

Handajani. (2006b). Pemanfaatan Tepung Azolla Sebagai Penyusun Pakan Ikan terhadap Pertumbuhan dan Daya Cerna Ikan Nila Gift (Oreochiomis sp). Jurnal Penelitian Gamma Vol. 1 No. 2.

Handajani. (2007c). Peningkatan nilai nutrisi tepung azola melalui fermentasi. Malang: Universitas Muhammadiyah Malang.

Handajani. (2007d). Pengaruh pemberian Bekatul Terfermentasi dengan Rhizophus sp sebagai Penyusun Pakan Ikan terhadap Daya Cerna dan Pertumbuhan Ikan Nila Gift. Prosiding Seminar Nasional Hasil Penelitian Perikanan dan Kelautan UGM (ISBN: 978-979-99781-2-7).

Handajani. (2011e). Optimalisasi Substitusi Tepung Azolla Terfermentasi Pada Pakan Ikan Untuk Meningkatkan Produktivitas Ikan Nila Gift. Jurnal Teknik Industri. 12 (2): 177-81

Haetami dan Sastrawibawa. (2005). Evaluasi Kecernaan Tepung Azolla dalam Ransum Ikan Bawal Air Tawar (Colossoma macropomum). Jurnal Bionatura, Vol 7, No 3, November 2005: 225 - 233.

Hapher B. (1990). Nutrition of Pond Fishes, New York: Cambridge, Cambridge University Press.

[KKP] KementrianKelautan dan Perikanan. (2009). Evaluasi Impor Bahan Baku Pakan Ikan dan Udang Berdasarkan SKT. Jakarta: DJPB, DKP.

Lumpkin, T.A \& D.L. Plucknet. (1982). Azolla a green manure: Use abd Management in Crop Production. Westview Tropical Agriculture Series.

Marhadi. (2009). Potensi Azolla (Azolla pinata) sebagai pakan berbasis local. http://marhadinutrisi06.blogspot.com/2009/04/potensi-Azolla-Azolla-pinnata-sebagai. html. [6 Oktober 2010].

Mudjiman, A. (2009). Makanan Ikan Edisi Revisi. Penebar Swadaya. Jakarta.

SNI. (1999a). Produksi Benih Ikan Nila Hitam (Oreochromis niloticus Bleeker) Kelas Benih Sebar. Badan Standarisasi Nasional. Jakarta, $13 \mathrm{hlm}$.

SNI. (2009b). Produksi Ikan Nila (Oreochromis niloticus Bleeker) Kelas Pembesaran di Kolam Air Tenang. Badan Standarisasi Nasional. Jakarta, $12 \mathrm{hlm}$.

Suriah, E. (2008). Optimalisasi Produksi Usaha Pembenihan Ikan Nila Gift di Kecamatan Cisaat Kabupaten Sukabumi. Skripsi. Fakultas Pertanian IPB. Bogor.

Webster CD, Liem C. (2002). Nutrient Requirements and Feeding of Finfish for Aquaculture. New York, USA: CABI Publishing. 
